\title{
Электропроводность многослойных монополярных ионообменных мембран
}

\author{
Шапошник В.А., Анисимова Н.О., Коровкина А.С. \\ ФГБОУ ВО «Воронежский государственный университет», Воронеж
}

Поступила в редакцию 19.05.2018 г.

DOI: https://doi.org/10.17308/sorpchrom.2018.18/538

Проведенные нами измерения электрического сопротивления пакетов монополярных ионообменных мембран дали возможность сделать вывод о малых величинах межмембранных электрических сопротивлениях. Это позволяет принципиально увеличить корректность контактноразностного метода измерения электропроводности мембран. Работа содержит результаты измерения зависимостей величин удельной электропроводности от частоты переменного тока. Экстраполяция низкочастотных зависимостей удельных электропроводностей на нулевую частоту даёт возможность получить величины близкие к удельным электропроводностям на постоянном токе с целью использования их при математическом моделировании электродиализа с ионообменными мембранами.

Ключевые слова: мембраны, ионный обмен, электрическое сопротивление, удельная электропроводность, контактно-разностный метод, межмембранные сопротивления.

\section{Electrical conductivity of multilayer monopolar ion-exchange membranes}

\author{
Shaposhnik V.A., Anisimova N.O., Korovkina A.S. \\ Voronezh State University, Voronezh
}

\begin{abstract}
The paper presents the results of measurements of electrical resistivity of multilayer ion-exchange membranes. For the measurement of electrical resistance has been applied to cell, in which between the electrodes was placed a package ion-exchange membranes. The membranes in the conductivity cell were in equilibrium with the pure water to prevent the ingress of non-exchanged sorbed electrolyte. The design of the cell allowed thermostating membranes and pure water. To measure the impedance meter was used LCR HITESTER HIOKI, which allows the values of the impedance to allocate its components-the active electrical resistance, capacitance and inductance. The results showed that intermembrane electrical resistivity is significantly lower than the electrical resistivity of the membranes themselves and the boundaries of the electrodemembrane. This proves the correctness of the contact-difference method for measuring the electrical conductivity of membranes, which consists in finding the difference between the electrical resistance of $n+1$ and $n$ membranes. The work also contains the results of measurements of specific electrical conductivity of heterogeneous cation exchange membranes MK-40 and anion exchange membranes MA-41 in the low frequencies of alternating current. Extrapolation of values of specific electrical conductivity of ion-exchange membranes to zero frequency allowed to determine electrical conductivity of membranes close to their values at constant current. Since electrodialysis with ion-exchange membranes is carried out at a constant current, such values are necessary for calculating the electrical parameters of electro-membrane processes and in formulating the boundary conditions of the boundary value problems of periodic and continuous electrodialysis kinetics with alternating cation-exchange and anion-exchange membranes.
\end{abstract}

Keywords: membranes, ion exchange, electrical resistance, electrical conductivity, contactdifference method, intermembrane resistance. 


\section{Введение}

Электрохимические характеристики ионообменных мембран - электрическое сопротивление, удельная электропроводность, молярная электропроводность, электрическая подвижность ионов, феноменологические коэффициенты проводимости, коэффициенты трения и коэффициенты диффузии - являются важнейшими кинетически характеристиками, которые получаются из измерений электрического сопротивления. Удельное электрическое сопротивление является паспортной характеристикой серийных ионообменных мембран.

Известны три метода измерения электросопротивления и удельной электропроводности мембран - разностный, контактный и контактно-разностный. Разностный метод появился задолго до синтеза ионообменных мембран [1]. Он может успешно применяться для измерения электропроводности концентрированных растворов и растворов электролитов средних концентраций. Так как при таких концентрациях равновесного раствора в мембрану проникает необменно сорбированный электролит, то результат измерения будет отражать как его свойства, так и свойства ионообменной мембраны. Истинную электропроводность ионообменной мембраны можно измерить только в равновесии с чистой водой, имеющей высокое сопротивление, что приводит к значительным ошибкам при применении разностного метода.

Контактный метод заключается в измерении электросопротивления мембраны, находящейся непосредственно между электродами [2]. Метод позволяет проводить измерения мембран, отмытых дистиллированной водой, но суммарное сопротивление включает не только сопротивление мембраны, но сопротивления слоя между электродами и мембраной. Из контактных методов наиболее распространен ртутно-контактный метод [3]. Он заключается в измерении сопротивления мембраны в ртути, в которую помещены металлические электроды. Основной трудностью является перемещение мембраны из равновесного раствора в ртутную ячейку.

Контактно - разностным методом проводят измерения в ячейке для контактного метода. Измеряют электросопротивление двух и одной мембран, по разности которых находят истинное электросопротивление мембраны. Кондуктометрическая ячейка позволяет проводить измерения в любом интервале концентраций равновесного раствора, а также в чистой воде, используя цилиндр, в который помещают раствор [4,5]. Кроме того, цилиндр с раствором подключается к ультратермостату, что позволяет проводить измерения при постоянной температуре и, варьируя её, измерять энергии активации электропроводности ионообменных мембран. Предполагается, что между двумя мембранами имеется сопротивление, которое снижает точность измерений контактно-разностным методом [6]. Первой задачей настоящей работы является измерение межмембранного сопротивления мембран с целью оценки корректности контактно-разностного метода.

Второй задачей работы является измерение контактно-разностным методом зависимости удельной электропроводности от частоты переменного тока, с целью экстраполяции величин на нулевую частоту, которая близка к удельной электропроводности мембран на постоянном токе, так как именно на постоянном токе проводят основной электромембранный процесс деминерализации растворов электродиализом с чередующими катионообменными и анионообменными мембранами.

\section{Эксперимент}

Рис. 1 показывает схему кондуктометрической ячейки для измерения электрического сопротивления ионообменных мембран, выполненную из плексигласа.

Шапошник и др. / Сорбционные и хроматографические процессы. 2018. Т. 18. № 3 
Ячейка состоит из корпуса и штока, в которых закреплены платиновые электроды. Корпус имеет цилиндр, заполняемый раствором и к которому подводятся стеклянные теплообменники для термостатирования. К штоку прикреплен металлический цилиндр, на который помещается разновес, необходимый для достижения контакта между мембранами. К электродам были подсоединены металлические проводники, связывающие их с мультимером LCR HITESTER HIOKI, позволяющим измерять импеданс, активное электросопротивление, электрическую ёмкость и индуктивность.

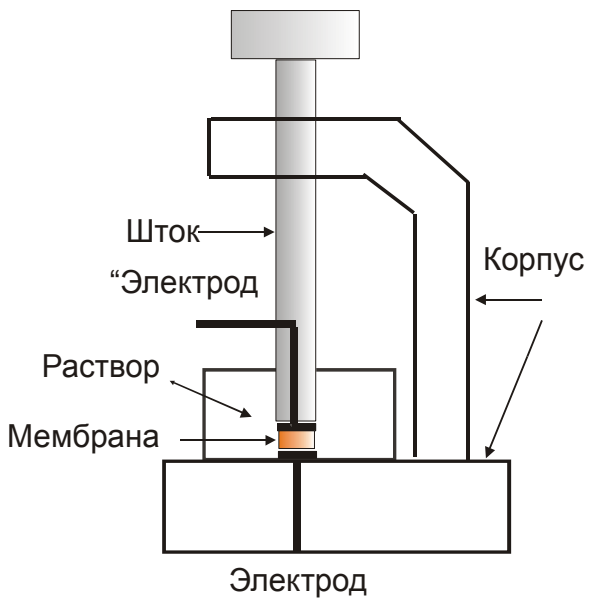

Рис. 1. Кондуктометрическая ячейка для измерения электропроводности мембран контактно-ртутным методом.

В работе были проведены измерения пакетов гетерогенных катионообменных мембран МК-40 и анионообменных мембран МА-41, изготовленных ОАО «Щекиноазот». Они представляли собой композиты, полученные прессованием 2/3 мелкодисперсных ионообменников и полиэтилена. Величины активных электросопротивлений были получены непосредственно с помощью мультимера, а удельные электропроводности рассчитывались по уравнению

$$
\kappa=\frac{d}{\left(R_{2}-R_{1}\right) S},
$$

в котором $\kappa$ - удельная электропроводность, $d$ - толщина мембраны, измеренная микрометром, $R$ - сопротивления мембран, $S$ - площадь мембран.

\section{Электросопротивления пакетов ионообменных мембран}

Были проведены измерения пакетов мембран, включающих до 5 мембран. Результаты измерений показаны на рис. 2 для катионообменных мембран МК-40 и на рис. 3 для анионообменных мембран МА-41.

Представленные на рис. 2 и 3 зависимости электрических сопротивления мембран от их числа в пакете являются линейными с коэффициентами корреляции в интервале $0.9932<\mathrm{r}<0.0 .9997$. При наличии межмембранных электросопротивлений линейные функции должны были превратиться в кусочно-линейные с разрывами непрерывности на межфазных границах. Таким образом, линейность зависимостей электрических сопротивлений от числа мембран даёт возможность пренебречь межмембранными электросопротивлениями, что устраняет замечания в адрес контактноразностного метода [4,5], сделанные в работе [6].

Шапошник и др. / Сорбционные и хроматографические процессы. 2018. Т. 18. № 3 


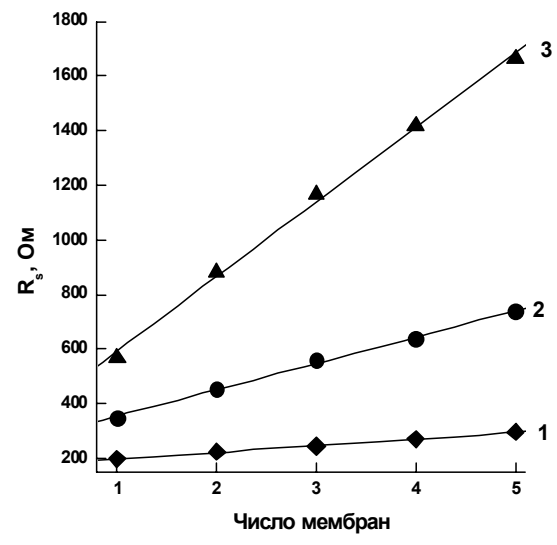

Рис. 2. Зависимость электросопротивлений катионообменной мембраны МК-40 от числа мембран в формах ионов натрия

(1), кальция (2) и алюминия (3).

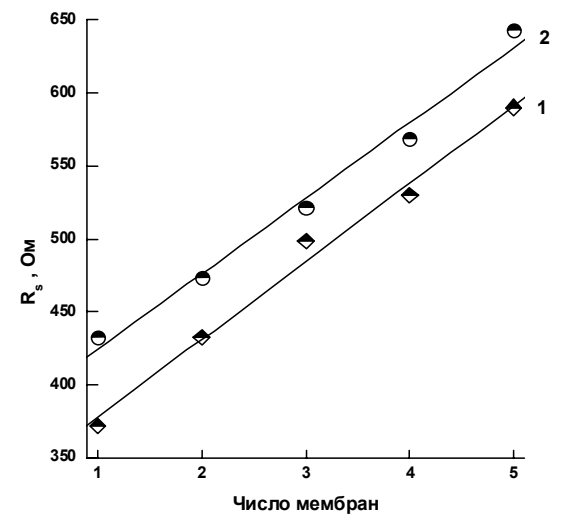

Рис. 3. Зависимость электросопротивлений анионообменной мембраны МА-41 от числа мембран в формах ионов хлора (1) и сульфата (2).

\section{мембран \\ Низкочастотные зависимости удельной электропроводности}

Удельная электропроводность мембран определяется по уравнению (1) из величин удельного электросопротивления, толщины и площади мембран. Она является одной из главных паспортных физико-химических характеристик. Из величины удельной электропроводности могут быть рассчитаны: молярная электропроводность $\lambda$, электрическая подвижность противоиона $u$ и приближенно с помощью уравнения Нернста-Эйнштейна кофффициент самодиффузии противоиона $D$.

$$
\lambda=\frac{\kappa}{C}, u=\frac{\lambda}{F} . D=k T u,
$$

( $C$ - концентрация, моль $/ \mathrm{cm}^{3}, k$,- постоянная Больцмана, $T$ - абсолютная температуpa).

Рис. 4 и 5 показывают зависимости удельной электропроводности мембран МК-40 и МА-41 от частоты переменного тока. Результат измерения показывает экспоненциальное увеличение удельной электропроводности с увеличением частоты переменного тока.

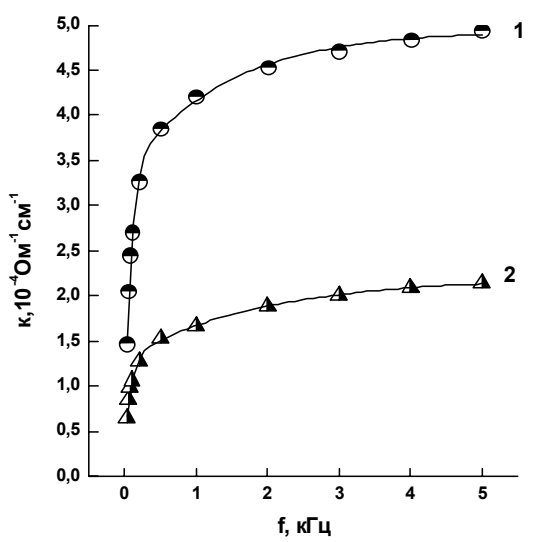

Рис. 4. Зависимость удельной электропроводности катионообменной мембраны MК-40 в форме ионов натрия (1) и кальция

(2) от частоты переменного тока.

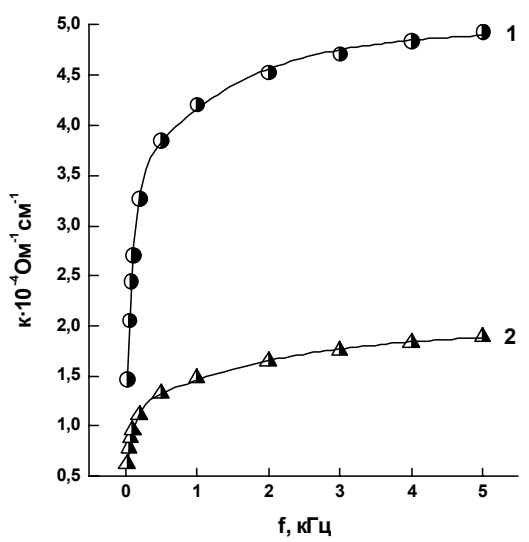

Рис. 5. Зависимость удельной электропроводности мембраны МА-41 в форме (хлорида (1) и гидрофосфата (2) от частоты переменного тока. 
Основным методом, в котором используются ионообменные мембраны, является электродиализ. Процесс электродиализа проводят на постоянном токе, а электропроводность измеряют преимущественно на переменном токе, чтобы избежать поляризации ионообменных мембран. Применяя экстраполяцию на нулевую частоту, мы получаем достаточно близкую величину к удельной электропроводности на постоянном токе. Такая величина необходима для расчета энергетических затрат при электродиализе и для формулировки краевых задач кинетики электродиализа

Для построения зависимостей, представленных на рис. 2-5 мы использовали программу Origin, которая позволяет по экспериментальным значениям получать эмпирические функции. Например, для удельной электропроводности мембраны МК-40 в форме ионов натрия было получено уравнение

$$
\kappa=4.94-2.53 \exp (-f / 0.082)-1.59(-f / 1.40),
$$

которое имеет коэффициент корреляции с экспериментальными величинами 0.9995. Уравнение 3 позволяет найти предполагаемую величину удельной электропроводности $0.82 \mathrm{OM}^{-1} \mathrm{~cm}^{-1}$. Эта величина отличается от удельной электропроводности, измеренной при 1 кГц в 5.3 раза, что принципиально меняет оценку энергозатрат при электродиализе. Снижение удельной электропроводности при применении постоянного тока объясняется наличием тормозящих электропроводность эффектов, аналогичных электрофоретическому и релаксационному эффектам в растворах электролитов.

\section{Заключение}

Отсутствие разрывов непрерывности линейных зависимостей электросопротивлений при измерение многослойных катионообменных и анионообменных мембран позволило сделать о пренебрежительно малом межмембранном сопротивлении, что позволяет увеличить корректность контактно-разностного метода измерения электропроводности мембран.

Измерение электропроводности ионообменных мембран как функции частоты переменного тока позволило экстраполяцией на нулевую частоту дать приближенную оценку электропроводности при постоянном токе, что дает возможность использования этой величины для расчета энергозатрат при электродиализе и при формулировании граничных условий второго рода при математическом моделировании электродиализа с чередующимися катионообменными и анионообменными мембранами.

\section{Список литературы}

1. Green A.A., Weech A.A., Michaelis L. // J. Gen. Physiol. 1929. Vol. 12. pp. 473-480.

2. Manecke G. // Z. Phys. Chem. 1952. Bd. 201. pp. 193-210.

3. Subrahmanyan V., Lakshminarayanaih N. // J. Phys. Chem. 1968. Vol. 72. pp. 4314-4316.

4. Шапошник В.А., Емельянов Д.Е., Дробышева И.В. // Коллоидный журнал. 1984. Т. 46. C. $820-822$.

5. Badessa T.S., Shaposhnik V.A. // Electrochemica Acta. 2017. Vol. 231. pp. 453-459.

6. Заболоцкий В.И., Никоненко В.В. Перенос ионов в мембранах. М. Наука. 1996. 392 c.

\section{References}

1. Green A.A., Weech A.A., Michaelis L., $J$. Gen. Physiol., 1929, Vol. 12, pp. 473-480.
2. Manecke G., Z. Phys. Chem., 1952, Bd. 201, pp. 193-210. 
4. Subrahmanyan V., Lakshminarayanaih N., J. Phys. Chem., 1968, Vol. 72., pp. 4314-4316.

4. Shaposhnik V.A., Emel'anov D.E., Drobysheva I.V., Rus. Colloid. J., 1984, Vol. 46, pp. 820-822.

Шапошник Владимир Алексеевич - д.Х.н., проф. кафедры аналитической химии Воронежского госуниверситета, Воронеж

Анасимова Наталья Олеговна - студент химического факультета Воронежского госуниверситета, Воронеж

Коровкина Анна Сергеевна - студент химического факультета Воронежского госуниверситета, , Воронеж
5. Badessa T.S., Shaposhnik V.A., Electrochemica Acta, 2017, Vol. 231, pp. 453-459.

6. Zabolotsky V.I., Nikonenko V.V. Ion transport in membranes, M., Nauka, 1996, 392 p.

Shaposhnik Vladimir A. - Dr. Sc., Prof., Department of Analytical Chemistry VSU, Voronezh, e-mail: v.a.shaposhnik@gmail.com

Anisimova Natalia O., student, Department of Analytical Chemistry VSU, Voronezh, e-mail: anisimova.nata2011@yandex.ru

Korovkina Anna S., student. Department of Analytical Chemistry VSU, Voronezh, e-mail: korovkina_anya96@mail.ru 